\title{
Reflections and Insights From Experiences Doing Quantitative
}

\section{Research}

\section{Gregory Sholdt \\ Konan University}

\section{Ken Schmidt}

Tohoku Fukushi University

\section{Asako Takaesu}

Soka University

\section{Roy Connolly}

Sano Nihon University College

\section{Christopher R. Cooper}

Rikkyo University

\section{Reference Data:}

Sholdt, G., Schmidt, K., Takaesu, A., Connolly, R., \& Cooper, C. (2020). Reflections and insights from experiences doing quantitative research. In P. Clements, A. Krause, \& R. Gentry (Eds.), Teacher efficacy, learner agency. Tokyo: JALT. https://doi.org/10.37546/JALTPCP2019-03

The 2018 Quantitative Research Training Project offered language teachers based in Japan an opportunity to learn about quantitative research methods, get practical experience doing classroom-based research, and collaborate throughout the process with a group of their peers. Four teachers share their insight from their experience doing this research to inform and encourage other language teachers. Schmidt describes how he overcame doubts to team up with a colleague and move forward with a quantitative study. Takaesu emphasizes the importance of monitoring student response rates to questionnaires to avoid shrinking sample sizes. Connolly writes about the effort and dedication required to complete a study. Cooper highlights how meaningful research can still be done with a small class. Teachers interested in building skills in classroom-based research are encouraged to explore opportunities to get more involved with the JALT community.

2018年の量的研究研修プロジェクトは、日本に拠点を置く語学教師に、量的研究方法について学び、教室での研究を実践 する経験を得て、仲間のグループとプロセスを通じて協力する機会を提供した。人の教師がプロジェクトでの経験から得た 洞察を共有し、他の語学教師に情報を提供し、奨励している。Schmidtは、同僚とチームを組み、定量的研究を進めることに対 する疑問を克服した。Takaesuは、サンプルサイズの縮小を避けるために、アンケートに対する学生の回答率を監視すること の重要性を強調している。Connollyは、研究を完了するために必要な努力と献身について共有している。Cooperは、少人数の クラスで有意義な研究を行うことができる方法を強調している。教室べースの研究でスキルを構築することに興味のある教師 は、JALTコミユニティにもっと関与する機会を探ることを勧める。

lassroom-based research can help teachers better understand their students, make evidence-based changes to their teaching, contribute to their fields, engage with their professional community (Borg, 2010; Brown \& Rodgers, 2009), and improve their employability (McCrostie, 2010). In response to an observed interest in building skills in classroom-based research methods from language teachers in Japan, Sholdt (2011a) developed a yearlong, online, professional development project centered on direct instruction in quantitative methods, guided practical experience involving a classroom study, and collaborative learning. The main project lasts an entire academic year with some continued project activity as study write-ups get finished and opportunities to present findings are pursued. The project can support 40 teachers, and participants are expected to keep up with online lessons, contribute to the discussion forum, and complete the classroom study, including data collection, analysis of the results, and publication of their findings. The project has been run three times since its inception in 2012 (Sholdt, 2011b, 2017b, 2018), with over 100 teachers participating in total. 
The 2018 Quantitative Research Training Project (2018QRTP) involved 32 language teachers based at 20 different universities across Japan and was conducted during the 2018 academic year (Sholdt, 2019). Each participating teacher received a procedures guide for a small-scale study on student engagement in an extensive reading activity and a schedule for data collection within the spring semester. This particular study was selected because of the popularity of extensive reading in Japan and appropriateness for a wide range of instructional settings. Twenty-eight teachers, working alone or in small teams, completed data collection and progressed to the second stage of the project-data analysis and study write-up. During the fall semester, teachers received guidance through online live lectures and a discussion forum. At the time of writing, 17 different manuscripts related to the project have been published by teachers involved in the project.

An emphasis of the 2018QRTP was collaboration among the participants with the goal of improving learning outcomes, raising awareness of research practices, providing encouragement, and developing community. Teachers worked together to produce critical materials such as a bilingual questionnaire for data collection, instructions on using Xreading.com, and administrative documents. When the study was underway, they shared experiences, asked questions, and gave advice about the implementation of the procedures. In the latter stages, teachers discussed how to set up database files, shared resources about statistics, and reviewed manuscripts. In this article, four of the project teachers share their personal reflections, each in their own voice, about their decision to get involved with the project, report the main findings from their research, describe issues they encountered during the research process, and provide tips for other teachers based on their own experiences. By sharing their backgrounds, thoughts, and experiences, they hope other language teachers can pick up specific ideas for their own projects and feel encouraged by those with limited training who have successfully taken steps to get more involved with classroom-based research.

\section{Overview of the Extensive Reading Study}

While each of the co-authors discusses and emphasizes different aspects of their research in their reflections, a short overview of the shared study procedures is presented here to help readers understand the study and reduce repetition in the individual sections.

Teachers in the project initially identified a course compatible with the weekly extensive reading activity. They placed students into small groups who worked together over an eight-week period. Using the Xreading.com online graded reader library, students either selected a personal reader on their own or a shared reader with their group during class. They completed the reading on their own outside of class for homework and then met with their groups the following week to discuss what they read. The goal of the research was to determine whether there were different levels of engagement in the three stages of the activity (selection, reading, discussion) depending on whether they chose their own individual reader or a shared reader with their groups. At each stage, students answered a short questionnaire covering different dimensions of engagement. The study was designed so that data collection could be conducted entirely within 1 semester and the analysis relied on basic statistical procedures that were introduced in the online lectures: descriptive statistics, repeated measures $t$-tests, and effect sizes. While SPSS was recommended for the data analysis, several teachers instead used PSPP, an open source application. Teachers adapted the design to best fit their particular setting, students, and interests.

\section{Participants' Personal Reflections}

Getting Past Personal Barriers-Ken Schmidt

Background

After 9 years of studying geology, I switched tracks and began a 31-year career in TEFL, mostly spent at universities in Japan. Despite an understanding of the scientific method and quantitative research concepts, and the collection of considerable data on student performance, attitudes and experiences, I had never published a quantitative study.

Attending Sholdt's (2017a) presentation on the 2018QRTP, I felt that this was my chance; either I join the project and make a start with quantitative methods, or simply continue publishing anecdotal accounts of methodology and student responses for the remainder of my career. A colleague, Cheinman Lee, agreed to partner with me, and we took the plunge.

\section{Research}

Our 10-week study involved 53 sophomores enrolled in two sections of a weekly, required, general-education English course at Tohoku Fukushi University. Following the general 2018QRTP scheme and specific procedures outlined in Sholdt (2019), we examined, through online questionnaires, the effects of self- vs. group-selection of readers on students' reported engagement (interest, enjoyment, concentration, effort) in each stage of the activity-selection, reading and discussion. Thirty-two students submitted questionnaires sufficient to be included in the analysis.

Across the board, engagement values were in the "moderate" range with no significant differences between self- and group-selection conditions, and only small effect sizes 
(Schmidt \& Lee, 2019). These were meaningful results, indicating that students found the activities similarly engaging, and that the choice between self- and group-selection could be made on grounds other than engagement (e.g., employing both approaches to provide variety).

\section{Issues Encountered}

The QRTP process clarified and helped me deal with several issues that had been personal barriers to quantitative research. One involved my own pride; I feared submitting a paper and being told, "You don't know what you're doing." In the QRTP, no expertise was expected, no question too dumb. This safe entry point was tremendously helpful. Another barrier involved the daunting prospect of producing a research proposal in Japanese and shepherding it through the ethics committee process. Having no idea what to expect, we initiated the process with trepidation. In our case, the committee judged that our study was within the frame of normal language pedagogy, and we were allowed to move forward quickly, provided informed consent procedures were followed. I was relieved by the ease with which we were able to liaise with the committee, and their practical approach. Participation in the QRTP encouraged me to take this step, and my previous apprehension proved largely unfounded.

A barrier familiar to many educators involves time use and multiple responsibilities. Over the years, I had temporarily set aside several research projects to deal with teaching and administrative duties, but ended up never returning to them. Pressure to provide updates to my research partner and QRTP leader brought accountability helpful in maintaining momentum despite competing commitments. The practical and moral support available through the QRTP also aided in overcoming difficulties. For example, running into serious problems with SPSS, I might have formerly thought, "Hmm... difficult. l'll get back to this next week... month... year." However, buoyed by QRTP colleagues happy to help if called on, I persevered and eventually solved the issues on my own - an unlikely result without the group safety net.

\section{Tips and Suggestions}

Based on my QRTP experience, I can offer some suggestions for others making a start with quantitative research. Cultivating a support and accountability network of colleagues can be invaluable in developing a solid research plan honed and carried out with the benefit of ongoing feedback. Setting intermediate goals, such as a conference presentation or preliminary report, is another way to stay on track and elicit helpful feedback. Also, keeping handy a notes file (notebook, smartphone) to record procedures, problems, observations, and so on, is vastly superior to relying on memory. Turning to research ethics approval, early liaising with your institution's committee can yield valuable insight on the application process and feedback on your evolving research plan. If using "syntax"-based statistical analysis software, like SPSS, learn the basic commands and insert documentation throughout the growing syntax file. This allows easy review and correction of mistakes, re-running of tests with different parameters, and more. Finally, do not let a fixation on statistical significance blind you to more important aspects of your data and results.

The 2018QRTP has been a small, but important step for me in getting past some barriers when starting quantitative research. My hope is that this step will yield dividends in contributions to classroom research moving forward.

\section{My Challenges with Quantitative Research-Asako Takaesu} Background

I have been teaching English to Japanese students at various proficiency levels for the last 24 years both part-time and full-time at universities and at a two-year English vocational school. In the last four years, I have also taught a practicum to students in a TESOL Master's program. My academic research interest has been in extensive reading and listening as well as content-based EAP using global issues, and I have done qualitative research in these fields. As my knowledge of quantitative research was limited to descriptive statistics, it was not easy for me to fully understand and evaluate other researchers' quantitative studies. Therefore, when I found out about this QRTP project, I felt the time was ripe for me to learn more about quantitative research? and signed up for it immediately.

\section{Research}

I conducted my research in my 1st-year general English courses at a private university in Tokyo. The participants were 36 students with an elementary proficiency level of CEFR lower/mid A2 at the time of the research. The research was conducted over 6 weeks in the 2018 spring semester with the aim of comparing students' level of engagement in an extensive reading activity in which a reader was selected individually or by a group. The results indicated that the method of selecting the graded reader did not significantly affect student engagement at any of the three stages of the extensive reading activity (Takaesu, 2019). 


\section{Issues Encountered}

My experience with qualitative research has taught me that unexpected challenges are the norm and this was certainly true doing this quantitative study as well. One of the biggest issues I encountered while conducting my study was the loss of usable data because of absences. Students who missed even one class could not participate in critical stages of the activity in this small-scale, short-term study. This resulted in a considerable reduction of usable data, from 36 to 16 participants in the end. I had the data I needed to progress through the QRTP program, but it did compromise the strength of my findings.

Another issue that confronted me was managing the large set of data generated from multiple weekly questionnaires and inputting it into statistical analysis software such as SPSS. Even though we had been forewarned about this, sorting the data required a great amount of time and patience. Also, as convenient as it was, inputting data in the correct manner caused me much anguish at times. Moreover, interpreting the results presented another hurdle for me, especially with regards to the meaning of non-significant statistical findings.

\section{Tips and Suggestions}

To avoid a drastically reduced sample size, I suggest carefully monitoring student absences and giving immediate make-up opportunities to those who fail to fully complete study activities. To do this, one option is to do data collection every other week rather than weekly, as I did. This would allow the researcher to monitor responses and give make-up activities in a timely manner. Although this would extend the data collection period, the likelihood of maintaining a more complete sample would be greatly enhanced.

To overcome the difficulty with the use of a statistical application as well as understanding the concepts and terminology of statistics, I found it extremely helpful to go online and watch tutorials on YouTube or other sites that can be easily found with the proper keyword search. To get a grip on how to analyze survey results, I was also able to get useful advice from case studies posted online, as well as seek advice from the project coordinator and other teachers in the project. My last recommendation is to work with a group of teachers like I did with the 2018QRTP. Through regular online meetings, I was able to connect with other fellow researchers who shared similar questions and frustrations. Exchanging ideas with them was not only helpful, but also an empowering experience for me.

\section{An Unexpected Journey Into Quantitative Research-Roy Connolly Background}

My journey began with an undergraduate degree in business management and a minor in Japanese language, so working for a decade in Japan managing and training assistant language teachers seemed like a natural start to my career. However, I was surprised to find that it was the teaching and training, rather than the management, that most engaged me professionally. As a result, I decided to focus on teaching full-time, finished an MS in TESOL, and accepted a position at a junior college.

I had for some time looked forward to doing research and publishing findings to expand the base of knowledge in the field. I quickly learned, however, that the struggle to plan a study and get it off the ground while keeping up with the regular duties of a fulltime instructor was far more difficult than I had imagined. Although my colleagues in my school were all amazing instructors, none were doing research in my field, so my first foray into quantitative research would seemingly need to be on my own. When I learned about the 2018QRTP, I recognized immediately that it was exactly what I needed to help get me started.

\section{Research}

In order to investigate whether learner agency affects the level of student engagement in an extensive reading activity, I collected data from 1st- and 2nd-year Japanese students studying English in a junior college. The study was performed over 8 weeks in a weekly 90-minute class. All participants had been born in Japan, attended public schools, and none had any previous experience with extensive reading, nor extended time in an English-speaking environment. For my study, I assigned the participants to their small groups based on reading ability level and ran four cycles of individually selected readers and four cycles of group selected readers.

I compared reported engagement scores for each stage of the activity (selection, reading, discussion) for the individually selected weeks and the group selected weeks using paired sample $t$-tests. In the end, I found no statistically significant differences in the levels of engagement when individually selected and when the readers were group selected. I did find in one area, engagement while reading, where the reported difference in engagement while reading approached significance in favor of individually selected readers, and I intend to investigate this further. I found it interesting to note that the participants generally reported moderate levels of engagement in most measures for the individual as well as group selected reader conditions. Perhaps variety in selection 
provides the spice of life in extensive reading; additional research might reveal more in this area as well.

\section{Issues Encountered}

There were three primary challenges that I faced while conducting this study. The first was the class time I needed to use to prepare students to participate in the study: explaining the goals of the study, how to answer the surveys using Google forms, and how to use the Xreading website. The time required for students to complete the full collection of surveys was also significant. Second was my sample size: Although not large to begin with, after the removal of students with incomplete data sets due to absences, my sample size was reduced even further. The third challenge was the level of effort I found necessary to learn and implement new procedures and concepts underlying the data analysis such as arranging the database, running analysis procedures, and interpreting results.

\section{Tips and Suggestions}

I found that setting aside a certain time every week to push forward with small manageable goals helped me to establish and maintain forward momentum. Although the other members of the QRTP were a great support, I believe that had I had a partner sharing the same commitment to the study, it would have helped me even more maintain motivation and weekly accountability of my pre-set research goals. Finally, I found the emotional and cognitive inertia needed to restart my study after pausing for a particularly busy period required much more energy than it would have done to simply keep plodding along. One step after the other led me to this journey's end.

Small Samples and Becoming Quantitative Research LiterateChristopher R. Cooper

\section{Background}

I moved to Japan in 2010 to work as an assistant language teacher in public schools, mainly at the elementary school level. Later, with the aim of working at the tertiary level, I decided to do an MA in TESOL at Sheffield Hallam University in the UK, which I completed in 2016. I found I enjoyed the research more than I expected, and postgraduation I did a research project introducing graded readers to 10- to 12-year-old learners in public elementary schools (Cooper, 2018). The data I collected included a lot of numbers, but my analysis did not go any further than working out means, which
I regrettably referenced using the more colloquial form, "averages." My quantitative research knowledge was severely lacking, so when I heard about the 2018QRTP upon securing my first university job in 2018, I signed up immediately.

Research

My context was a small private university in the Kansai region of Japan. I had 12 participants at the beginning of the study, but that was reduced to eight due to absences. Their proficiency was around CEFR level A1 to A2. The students read online graded readers using Xreading (xreading.com), and I compared their engagement when reading individually selected graded readers versus ones that were selected as a group in alternate weeks for six weeks. There was no significant difference observed in engagement between the two conditions, suggesting instructors should not be deterred from trying extensive reading in their classrooms with group-selected graded readers rather than only self-selected readers, which is a feature of most extensive reading courses (The Extensive Reading Foundation, 2011). The results of the study are discussed in detail in a published article (Cooper, 2020).

\section{Issues Encountered}

The first issue I encountered was my small sample size. Some researchers suggest a minimum sample of 30 participants when conducting quantitative research (Phakiti, 2015). Despite finding myself with only 12 students in the two classes that were suitable for the study, I decided to continue with the project. This was mainly to improve my knowledge of quantitative research and I acknowledged resulting methodological weaknesses in my write-up. The second issue I encountered was understanding quantitative-based literature. Pre-QRTP, I was guilty of focussing mainly on the discussion and conclusion parts of quantitative research papers, and almost blindly accepting the researcher's claims, due to a lack of understanding of results tables. This did not allow me to critically evaluate results compared with the researchers' claims when judging the validity of the research paper.

\section{Tips and Suggestions}

I would suggest two things to overcome a small sample size. First, start collecting data as early as possible in the semester to avoid dropping students from the study, which is not ideal, as the goal is to maximize the sample size by[?] including regular absentees. The second thing I would suggest is to not chase $p<0.05$, or statistical significance. It is also 
possible to focus on other points in the analysis, such as discussing overall mean scores, the degree of difference between raw mean scores, and effect sizes such as Cohen's $d$ (Cohen, 1988). Calculating the effect size when the results are not statistically significant is not always recommended, but it can be useful when deciding whether to conduct further research in the same area with a larger sample.

To overcome the hurdle of understanding quantitative research, I would recommend starting with general research methods books (e.g., Dörnyei, 2007; Phakiti, 2015), then doing extensive reading of interesting quantitative papers. I would also suggest searching for multiple explanations of the same quantitative concepts and statistics on YouTube. In addition, there are some useful podcasts, such as Statistics for the Social Sciences (Fulton, 2019-present), which I found to be very good for building a foundation of knowledge about statistical concepts. Additionally, Data Skeptic (Polich \& Da Tran, 2014-present) is mainly about natural language processing but has some concise episodes on topics such as the $t$-test and ANOVA. Finally, the support provided by peers online in the QRTP was invaluable. Taking part in some kind of interaction about quantitative research with colleagues or peers, either in person or online, is not only helpful, but probably necessary for many research-practitioners if they are to continue conducting and understanding quantitative research.

\section{Conclusion}

A Look at the Reflections

Like many in Japan's language teaching community, Ken, Asako, Roy, and Christopher have different backgrounds, careers, and interests, but they all saw value in building their knowledge and skills in quantitative methods and found the determination to take on such a challenging mission. They each successfully conducted a meaningful quantitative study from start to finish while gaining valuable experience and insight along the way. The specific issues they encountered are typical of classroom-based research and welldiscussed in research methodology textbooks. However, reading about them in general terms and dealing with unique instances in real time while trying to teach a class, meet program goals, collect data for a study, and manage all of life's other responsibilities provides a very different perspective. Simple, small-scale, short-term studies are great opportunities to gain experience and knowledge as you build up to bigger research.

In the process of conducting their studies and exploring the concepts and procedures underlying quantitative methods, the four teachers were able to share their experiences with other project participants as well as receive advice and support in order to successfully overcome or best manage the issues they encountered. All four emphasized the value of this collaboration and have sought to extend it to peers outside the project through sharing their experiences and ideas in this article. Ultimately, we hope that other language teachers can recognize their own situations, interests, and goals in these reflections, gain from what was shared, and feel motivated to take first steps of their own.

\section{Moving Forward}

Even outside of a project like the QTRP, valuable collaboration can still be found. When looking to start a new research project, try to find a partner or form a small team. You can do a single study together or each concurrently replicate the same study as was done in the QRTP. Start a dialogue early in the planning process and pool your knowledge regarding selection of research topics, study design, data analysis, and publication opportunities. Seek outside support and resources when your team reaches its limits. There are great benefits to connecting with the larger community of language teachers in Japan, especially through JALT. Local chapter meetings, SIG-organized conferences, and the annual national conference allow for personal interaction, exposure to new ideas, and inspiration for future endeavors. Articles in The Language Teacher, JALT Journal, and numerous SIG-produced publications can provide model designs that can be adapted for research in personal areas of interest. Finally, reaching out to other JALT members with shared research interests or helpful areas of expertise to solicit feedback on your research ideas or start a dialogue may open avenues for collaboration. The more a teacher feels connected and receives support in their research, the greater the chance for success and a positive experience.

\section{Bio Data}

Gregory Sholdt studied educational psychology at the University of Hawai'i and has been teaching in Japan for over 20 years. He is currently based at Konan University. His interests include professional development for language teachers, classroombased research methods, English for academic purposes, and extensive reading. He is a consulting editor for the JALT Journal and a member of the JALT Research Grants Committee.<gsholdt@gmail.com>

Ken Schmidt has been teaching English in Japan for 28 years, the last 15 at Tohoku Fukushi University, Sendai. He holds an MA in TEFL from Southern Illinois University. His interests included extensive reading, course design and language learners' attitudes and experiences. <kjswork88@gmail.com> 
Asako Takaesu has been teaching English in Japan for 24 years and currently works at Soka University in Tokyo. She holds an MA in American studies from Michigan State University. Her research interests include extensive reading, extensive listening, contentbased EAP using global issues, and media literacy. <asatakaesu@gmail.com>

Roy Connolly has been teaching and training in Japan for 14 years and is currently teaching at Sano Nihon University College. He holds an MS in TESOL from Wilkes University. His research interests include English for academic purposes, extensive reading, and task-based learning. <roy.connolly@gmail.com>

Chris Cooper has been teaching English in Japan since 2010 and currently works at Rikkyo University in Tokyo. He holds an MA in TESOL from Sheffield Hallam University. His research interests include extensive reading, extensive listening, task-based language teaching, and corpus linguistics. <cooperchris17@gmail.com>

\section{References}

Borg, S. (2010). Language teacher research engagement. Language Teaching, 43, 391-429. https:// doi.org/10.1017/S0261444810000170

Brown, J. D., \& Rodgers, T. S. (2009). Doing second language research. Oxford: Oxford University Press.

Cohen, J. (1988). Statistical power analysis for the behavioral sciences (2nd ed.). Hillsdale, NJ: L. Erlbaum Associates.

Cooper, C. R. (2018). Rakudoku: Fostering the beginnings of extensive reading (with 5th and 6th graders) in a public elementary school in Japan. Journal of Extensive Reading, 6(2), 23-29. Retrieved from http://jalt-publications.org/content/index.php/jer/article/view/141

Cooper, C. R. (2020). Engagement with the selection, reading and discussion of online graded readers, a comparison between individual and group selected conditions. The Journal of International Languages and Cultures, Himeji Dokkyo University, 1, 21-38.

Dörnyei, Z. (2007). Research methods in applied linguistics. Oxford: Oxford University Press. Fulton, B. (Host). (2019-present). Statistics for the social sciences [Audio podcast]. Retrieved from https://anchor.fm/statistics/support

McCrostie, J. (2010). The right stuff: Hiring trends for tenured university positions in Japan. The Language Teacher, 34(5), 31-35. https://doi.org/10.37546/JALTTLT34.5-2

Phakiti, A. (2015). Quantitative research and analysis. In B. Paltridge, \& A. Phakiti (Eds.), Research methods in applied linguistics: A practical resource (pp. 27-48). London, England: Bloomsbury Publishing.
Polich, K., \& Da Tran, L. (Hosts). (2014-present). Data skeptik [Audio podcast]. Retrieved from https://dataskeptic.com

Schmidt, K., \& Lee, C. (2019). The effects of self- versus group-selection on engagement in a graded reading activity. Extensive Reading in Japan, 12(2), 11-12. Retrieved from http://hosted.jalt.org/er/ sites/jalt.org.er/files/ERJ/erj_issue_12.2.pdf

Sholdt, G. (2011a). Getting started with quantitative research: A first study. The Language Teacher, 35(4), 52-54. Retrieved from https://jalt-publications.org/sites/default/files/pdf/the_language_ teacher/35.4tlt.pdf

Sholdt, G. (2011b). Report on the development and pilot of a Moodle-based teacher research training project. Journal of the School of Languages and Communication, Kobe University, 8, 69-80. Sholdt, G. (2017a, November). 2018 Quantitative Research Training Project. Paper presented at the JALT2017 International Conference, Tsukuba, Japan.

Sholdt, G. (2017b). Procedures for a first-step quantitative study: Exploring written fluency. In P. Clements, A. Krause, \& H. Brown (Eds.) Transformations in language education (pp. 377-386). Tokyo: JALT. Retrieved from https://jalt-publications.org/files/pdf-article/jalt2016-pcp-049.pdf Sholdt, G. (2018). The 2018 Quantitative Research Training Project: First stage progress report. Extensive Reading in Japan, 11(1), 14-17. Retrieved from http://hosted.jalt.org/er/sites/jalt.org.er/ files/ERJ/erj_issue_11.1.pdf

Sholdt, G. (2019). Sharing experiences from the 2018 Quantitative Research Training Project. Extensive Reading in Japan, 12(2), 3-5. Retrieved from http://hosted.jalt.org/er/sites/jalt.org.er/ files/ERJ/erj_issue_12.2.pdf

Takaesu, A. (2019). Impact of selection method on elementary students' engagement in ER. Extensive Reading in Japan, 12(2), 9. Retrieved from http://hosted.jalt.org/er/sites/jalt.org.er/files/ ERJ/erj_issue_12.2.pdf

The Extensive Reading Foundation. (2011). The Extensive Reading Foundation's guide to extensive reading. Retrieved from http://erfoundation.org/guide/ERF_Guide.pdf 